FACTA UNIVERSITATIS

Series: Physical Education and Sport, Vol. 18, No 3, 2020, pp. 601 - 609

https://doi.org/10.22190/FUPES201130058K

Narrative review article

\title{
MUSCLE ACTIVATION DURING FOREHAND AND BACKHAND DRIVES IN THE SPORT DISCIPLINE OF TENNIS
}

\author{
UDC 796.342:591.473
}

\author{
Vasilios Koronas $^{1}$, Nikolaos Koutlianos ${ }^{2}$ \\ ${ }^{1}$ Private College “Apostolos Pavlos”, Panorama, Thessaloniki, Greece \\ ${ }^{2}$ Faculty of Physical Education and Sport Sciences, Aristotle University of Thessaloniki, \\ Thessaloniki, Greece
}

\begin{abstract}
Tennis is one of the most popular individual sports all over the world. Strength and trained muscles are required for a player in order to achieve a good backhand, forehand, volley or flat stroke. Especially while playing tennis are many kinds of muscles involved, including the lower body muscles, trunk muscles and upper body muscles. The purpose of this review is to present the activated muscles in the basic tennis movements of forehand and backhand and to improve the knowledge about their role in order to help tennis players and coaches to enhance their tennis performance and to reduce risk of injury. To support the present review, data were gathered from library and network databases using keywords such as tennis, muscles, forehand, and backhand for publications between 2015 and 2019. Overall, thirty-five references were detected and used. The literature showed that forehand and backhand drives are strokes that involve muscles not only of the upper limbs but also a series of more complex movements that start with the feet and end with the swinging of the tennis racket. The insight for the action of the muscles in tennis should be utilized in tennis players so as to better understand the muscular function which takes part in specific tennis movements and has a greater performance. In addition, this knowledge is considered strongly beneficial for the coaches and the favourable building of the training process.
\end{abstract}

Key words: Tennis, Muscle, Tennis Stroke, Forehand, Backhand

Received November 30, 2020 / Accepted December 12, 2020

Corresponding author: Vasilios Koronas

Private College "Apostolos Pavlos", Tzon Kennenti 119, Pilea Chortiatis 555 35, Thessaloniki, Greece

Phone: + 302310321110 •E-mail: b.koronas@yahoo.gr

(ㄱ) 2020 by University of Niš, Serbia | Creative Commons License: CC BY-NC-ND 


\section{INTRODUCTION}

The human muscular system is made up of striated or skeletal muscles. The study of muscles in general, especially in terms of energy, is very interesting and essential for understanding the motor functions of the human body. The alternating energy of the muscles on the bones and joints achieves the harmonious kinetic functions of body parts, which are unlimited, e.g. the upright posture, the gait, the upper limb conceiving abilities, the hormonal motions of the torso to maintain balance, etc. (Capitano, Moriggi, \& Gelfi, 2017; Tohanean, 2018; Lai, Biewener, \& Wakeling, 2019; Alexe, Alexe, Tohanean, \& Tudose, 2020).

This review addresses the activated muscles during the basic strokes of forehand and backhand drives in the very popular racquet sport discipline of tennis. It is noteworthy that during the action of a muscle not all muscle fibers are contracted, but only certain motor units, depending on the mechanical work performed. The bigger the project, the more motor units operate. Muscle force is exerted on the adhesive points of the muscle.

Almost all the body muscles are involved in tennis. Many of the muscle actions regarding the lower body are just the same for all the tennis strokes (Ivančević, Jovanović, Đukić, Marković, \& Đukić, 2008; Elce et al., 2017; Roeter \& Kovacs, 2019). At the same time, they workout evenly and develop rapidly in racing tennis. They derive their energy from the breakdown of ATP (adenosine triphosphate), which is the direct source of energy. However, ATP is not always enough for the energy which is in need. Thus, ATP is reconstituted from indirect sources of muscle energy, such as CP (phosphocreatine - three times the amount of ATP), glycogen and fats (Rodrigues, \& Del Valle, 2018; Sawali, 2018). The first case applies to relaxed movements in rest and preparation while the second occurs in intense and fast movements. The muscles in tennis act isotonic and isometric. The isometric contraction is mainly about the racket handle as well as the bent legs at standby. It is essential for the muscles which act isometric to be extremely well-trained, because a strong and good stroke depends on a firm grip and strong legs (quadriceps, thighs) (Zhang et al., 2016; Colomar, Baiget, \& Corbi, 2020)

The purpose of this review is to present the activated muscles in the basic tennis movements of forehand and backhand and to improve the knowledge about their role in order to help tennis players and coaches enhance their tennis performance and reduce risk of injury.

\section{METHODS}

In order to elaborate this review, we have identified numerous updated bibliographic sources that have focused on scientific aspects regarding the way in which the muscles of the human body are involved in performing the usual movements, but also of some procedures specific to the game of tennis. Bibliographic sources aimed at the field of human anatomy and physiology, physiotherapy, kinesiology, but also studies that refer to interdisciplinary fields were accessed. Among the latter, of interest are those with a predilection focused on performance training in tennis. In this regard, various international databases were accessed (Web of Science, Scopus, Springer Link, DOAJ and Google Scholar). We have given specific attention to the bibliographic sources from the last five years, with the idea of highlighting new aspects of the topic we researched. 


\section{THEORETICAL CONSIDERATIONS OF THE PROBLEM}

\section{Tennis movements and muscular activation}

\section{A. Grip}

The following analysis applies to any grip used: Eastern, Continental, Semi-continental. To tighten the fingers and palm on the racket the activation of the following is necessary: flexor digitorum superficialis, palmaris longus, flexor carpi ulnaris, flexor pollicis longus and flexor digitorum profundus (Burute \& Vatsalaswamy, 2017; Hodde, Ioannou, \& Altenmuller, 2019).

They are anterior and posterior muscles of the forearm, which flex the fingers and the wrist. The flexor carpi radialis is responsible for the angle formed between the racket and the forearm. The opening of the toes to change the grip is made by the muscles of the dorsal side of the forearm - the extensor surface - which include: the extensor carpi radialis longus, extensor carpi radialis brevis, extensor digitorum communis muscle, extensor digiti minimi proprius, extensor carpi ulnaris, extensor pollicis brevis (West, Ricketts, \& Brassett, 2017; Save \& Fishman, 2019).

The pronator quadratus with the pronator teres takes part in the change from the Eastern to the Continental grip.

\section{B. Standby position}

The preparation of each player for a stroke starts from the standby position, also called the basic position. For the two basic strokes, the forehand and backhand, the standby position is the same.

The player stands with his feet as wide as the shoulders. The knees are slightly bent and the body weight is evenly distributed on the legs and even more on the tiptoes, the body has a slight inclination forward. The racket is held with both hands in front of the body with bent elbows close to the body. The hold is made in such a way that the head of the racket is higher than the grip. Therefore, in this position all the muscles in the body are in increased muscle tone. However, it does not seem to produce and generate traffic. This is because the muscles work isometrically.

C. Basic strokes

C.1. Forehand Drive

The term forehand is used as a base for all the strokes from the right position for the right-handed and the opposite for the left-handed (Agrotou, 2015).

a) Preparation phase

In the preparation phase, in order to lift the hand holding the racket to the horizontal position, the lateral deltoid is contracted with the posterior deltoid leading to the abduction and outward turn of the arm. Also, the teres minor and teres major muscles are involved. For the flexion of the elbow, the anterior arm is contracted by working with the biceps brachii. Turning the torso to the right is achieved after the right obliquus internus abdominis muscle and the left obliquus extremus abdominis muscle. The transversospinal muscular system also helps. The right sternocleidomastoid muscle is involved in preventing the head from turning when the torso turns right.

The slight inclination of the torso is helped by the abdominal muscles. The walking muscles such as the iliopsoas, sartorius and pectineus muscle are activated during the 
preparation steps. Ancillary muscles are the adductor magnus (upper bundles), the adductor minimus, the adductor longus and the tensor fascia lata muscle (Genevois, Creveaux, Hautier, \& Rogowski, 2015). The main muscles for the extension of the tibia are the quadriceps, which comprises the rectus femoris, the vastus lateralis, the vastus medialis and the vastus intermedius. The activated muscles for the dorsal flexion of the footing are the tibialis anterior, the anterior perineum and the extensor digitorum longus. The ancillary muscle is the extensor hallucis. The main muscles for flexion of the tibia are the biceps femoris, the semimembranosus and the semitendinosus. Ancillary muscles are the sartorius muscle, the gracilis, the popliteus muscle, the gastrocnemius and the soleus muscle. In addition, for the left foot to move right and in front of the above walking muscles, the adductor muscles (the adductor magnus, the adductor minimus, the adductor longus and the gracilis) also participate (Zdilla, Paulet, Lear, Addie, \& Lambert, 2018; Olewnik, Podgorski, M., Polguj, M. Ruzik, K., \& Topol, 2019; Bordoni \& Varacallo, 2020).

b) Hitting phase

To move the right hand (with the racket) forward where it will hit the ball, the pectoralis major is contracted, working with the anterior deltoid. Also, in order to stretch the hand, the triceps with the elbow muscle is contracted. To restore the torso forward, the left obliquus internus abdominis muscle works with the right obliquus extremus abdominis muscle. For stretching the legs, the quadriceps act mainly, and for the lifting of the heel from the ground (where the next step will be followed) the muscles of the plantar flexion are involved. The main muscles are the gastrocnemius and the tibialis posterior.

The auxiliary muscles are the soleus, the peroneus longus, the peroneus brevi, and the tibialis posterior. The left hand makes a slight bend in the elbow where the biceps brachii and anterior arm contract and is usually abandoned in inertia forces (Jarmey \& Sharkey, 2015; Whiting, 2019).

c) Final phase

With the start of the preparatory phase, the hand remains almost stretched and then bends. Its direction is from the bottom to front and up and left. This movement of the right hand involves the anterior portion of the deltoid muscle along with the pectoralis major muscle, which pulls the arm inward. Additionally, the shoulder blade is directed forward, the muscles that contribute to this movement are the rhomboid and the serratus anterior muscle. The right foot is ready to leave the ground and take a new step, with the gastrocnemius and the tibialis posticusmuscle working together (Maharaj, Cresswell, \& Lichtwark, 2016; Martin, Bideau, Delamarche, \& Kulpa, 2016; Larionov, Yotovski, \& Filgueira, 2018).

\section{C.2. Backhand Drive}

The standby position is the same as for the forehand drive.

a) Preparation phase

At the beginning of the preparation phase, the wrist (with the racket) is bent and the whole hand is driven to the left. The left hand also helps in this movement. This bending is mainly due to the contraction of the flexor digitorum superficialis; also, the auxiliary muscles carry most of the flexor digitorum (Roeter \& Kovacs, 2019).

With the energy of the anterior portion of the deltoid and pectoralis major muscle, the right arm slightly rises and moves to the left. For the flexion of the forearm towards the 
arm, the anterior arm with the biceps brachii cooperates contracted. The flexors muscles of the fingers of the left hand are activated to hold the racket from the neck, which act isometrically and are mentioned on the previous page. To pull the same hand backwards and inwards, the teres major, the infraspinatus and the posterior deltoid are contracted. The torso and hips point to the left from the left obliquus internus abdominis muscle, the right obliquus extremus abdominis muscle, and the transversospinal system. Contracting the right rectus abdominis with the obliquus internus abdominis muscle the obliquus extremus abdominis muscles lean the torso forward and right (Genevois, Reid, M., Rogowski, I., \& Crespo, 2015; Kumar \& Kumar, 2017).

In order for the left foot to move left and forwards and then to follow the right foot to the left and front, the walking muscles (flexors of the tibia, thigh, soleus and extensor muscles attached to them, as well as the adductors with the abductors muscles) must cooperate and contract at the same time, reported in detail in the steps of the forehand drive (Fields \& Rigby, 2016).

b) Hitting phase

The hand holding the racket is guided downwards and forwards where the racket will strike the ball at the extension of the right foot and at approximately the height of the knee. Therefore, in order to move the right arm forward (anatomically backwards) and below, the posterior deltoid, the supraspinatus and the teres major are involved. The triceps, working with the elbow muscle, extend the forearm just before hitting. As for the shoulder blade, it is raised up and back with the contraction of the rhomboid muscle and the levator scapulae. Also, the torso extends backward with the energy mainly of the two latissimus dorsi muscles and spinal extensor muscles. The legs are stretched with the contraction of the quadriceps, the gastrocnemius and the tibialis posterior muscle (Bolsterlee, D’Souza, Gandevia, \& Herbert, 2017; Özek, 2020).

\section{c) Final phase}

The right hand begins to move away from the torso, continuing the movement until the arm reaches approximately a horizontal position. In this movement the deltoid and especially the lateral, the coracobrachial, supraspinatus, in cooperation with the upper trapezoid slightly elevate the shoulder blade. At this stage, the player rests on his toes and is ready for the move. The weight of the body lies mainly on the right foot. The gastrocnemius, the tibialis posterior, the peroneus longus, brevis, and the tibialis posterior act all in this (Bisschops \& Lavallee, 2016; Saeki et al., 2018).

To restore the torso and hips from the turn that it had already made in the preparatory phase, the right obliquus internus abdominis muscle and left obliquus extremus abdominis muscle take part, even the transversospinal system that includes the semispinalis muscle, the multifidus muscle and the rotators. In order to keep the head-face fixed in a position that sees the coming ball and not to be dragged by the corners of the torso, the sternocleidomastoid and the semispinal act primarily (Sanchis-Moysi et al., 2016; Myers \& Kibler, 2018; Amaro, Paulino, Neto, \& Roseiro, 2019).

Finally, it is noteworthy to report that the descriptions of the techniques are about the right-handed, the exact opposite is valid for the left-handed. The activated muscles in the aforementioned basic tennis movements are presented in Table 1. 
Table 1 Muscles action in basic hits in tennis.

\begin{tabular}{|c|c|c|}
\hline & $\begin{array}{l}\text { Movements - } \\
\text { Stroke techniques }\end{array}$ & Muscles in action \\
\hline & Grip & $\begin{array}{l}\text { flexor digitorum superficialis, palmaris longus, flexor carpi } \\
\text { ulnaris, flexor pollicis longus and flexor digitorum profundus, } \\
\text { extensor carpi radialis longus, extensor carpi radialis brevis, } \\
\text { extensor digitorum communis muscle, extensor digiti minimi } \\
\text { proprius, extensor carpi ulnaris, extensor pollicis brevis, } \\
\text { pronator quadratus, pronator teres }\end{array}$ \\
\hline & Standby position & All body muscles work isometrically and in increased muscle tone \\
\hline \multirow{3}{*}{ 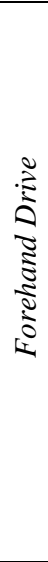 } & Preparation Phase & $\begin{array}{l}\text { lateral deltoid, posterior deltoid, teres minor and teres major, } \\
\text { biceps brachii, obliquus internus and extremus abdominis, } \\
\text { sternocleidomastoid, iliopsoas, sartorius, pectineus, adductor } \\
\text { magnus (upper bundles), adductor minimus, adductor longus, } \\
\text { gracilis, tensor fascia lata, rectus femoris, vastus lateralis, vastus } \\
\text { medialis, vastus intermedius, tibialis anterior, anterior perineum, } \\
\text { extensor digitorum longus, extensor hallucis, biceps femoris, } \\
\text { semimembranosus, semitendinosus }\end{array}$ \\
\hline & Hitting Phase & $\begin{array}{l}\text { pectoralis major, anterior deltoid, triceps, elbow, left obliquus } \\
\text { internus abdominis, right obliquus extremus abdominis, } \\
\text { quadriceps, plantar flexion, gastrocnemius, tibialis posterior, } \\
\text { soleus, peroneus longus, the peroneus brevi, tibialis posterior, } \\
\text { biceps brachii, }\end{array}$ \\
\hline & Final Phase & $\begin{array}{l}\text { deltoid, pectoralis major, rhomboid, serratus anterior, } \\
\text { gastrocnemius, tibialis posticus muscle }\end{array}$ \\
\hline \multirow{3}{*}{ 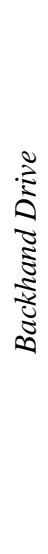 } & Preparation Phase & $\begin{array}{l}\text { flexor digitorum superficialis, deltoid, pectoralis major muscle, } \\
\text { biceps brachii, flexors muscles of the fingers, teres major, the } \\
\text { infraspinatus and the posterior deltoid, right rectus abdominis } \\
\text { with the obliquus internus abdominis muscle and the obliquus } \\
\text { extremus abdominis muscles, right rectus abdominis, obliquus } \\
\text { internus abdominis, obliquus extremus abdominis, flexors of } \\
\text { tibia, thigh, soleus, adductors, abductors }\end{array}$ \\
\hline & Hitting Phase & $\begin{array}{l}\text { posterior deltoid, the supraspinatus, teres major, triceps, elbow, } \\
\text { the rhomboid, levator scapulae, latissimus dorsi, spinal extensor, } \\
\text { quadriceps, gastrocnemius, tibialis posterior }\end{array}$ \\
\hline & Final Phase & $\begin{array}{l}\text { deltoid, lateral, coracobrachial, supraspinatus, upper trapezoid, } \\
\text { gastrocnemius, tibialis posterior, peroneus longus, brevis, } \\
\text { tibialis posterior, obliquus internus abdominis, left obliquus } \\
\text { extremus abdominis muscle, semispinalis, multifidus, rotators, } \\
\text { sternocleidomastoid, semispinal }\end{array}$ \\
\hline
\end{tabular}




\section{CONCLUSIONS}

Tennis is a sport that involves muscles not only of the arms and wrists but also a series of complex movements which begin from the feet and end in a racket swing as the final move. It requires a well-trained and honed set of muscles to execute movement with the speed needed as well as the power that is demanded regardless of the player's tennis level. That is because each player uses the same group of muscles in all of them. The feet movements used for jumping and running are the initial links, which are followed by hips, legs, trunk, arms and the hand at last. Initially, muscles of the lower body are the first group involved when playing tennis. Following up are the upper legs, which include the quads and the hamstrings. The energy and power are transferred to the gluteus maximus and medius. The group of trunk muscles are next in the continuous kinetic action. Finally, regarding the upper body it includes the major muscles, and the upper back mainly sets in motion the rhomboid and trapezius, which continue to the upper arms. The last muscles that also take part are the flexor and extensor of the antibrachium.

The insight for the action of the muscles in tennis should be effectively utilized in tennis players in order to enhance their physical performance. Moreover, this knowledge is considered strongly helpful for the coaches and the favourable building of the training process as well as for the sports doctors and physiotherapists coping with injuries in tennis players.

\section{REFERENCES}

Agrotou, S. (2015). Notes for the course of tennis. Athens. Department of Physical Education and Sports Science, National and Kapodistrian University of Athens.

Alexe, D.I., Alexe, C.I., Tohanean, D.I., \& Tudose, A.V. (2020). Mijloace utilizate in pregatirea, monitorizarea, profilaxia, refacerea si cercetarea din domeniul sportului (Means used in training, monitoring, prophylaxis, recovery and research in the field of sports). Cluj-Napoca: Risoprint. In Romanian

Amaro, A.M., Paulino, M.F., Neto, M.A., \& Roseiro, L. (2019). Hand-arm vibration assessment and changes in the thermal map of the skin in tennis athletes during the service. International Journal of Environmental Research and Public Health, 16(24), 5117.

Bisschops, J., \& Lavallee, M. (2016). Anatomy of the leg. In: J. Dixon (Ed.), Muscular injuries in the posterior leg. Boston, MA: Springer.

Bolsterlee, B., D’Souza, A., Gandevia, S.C., \& Herbert, R.D. (2017). How does passive lengthening change the architecture of the human medial gastrocnemius muscle? Journal of Applied Physiology, 122(4), 727-738.

Bordoni, B., \& Varacallo, M. (2020). Anatomy, bony pelvis and lower limb, thigh quadriceps muscle. In: StatPearls, Treasure Island (FL): StatPearls Publishing.

Burute, P., \& Vatsalaswamy, P. (2017). Accessory heads of forearm flexors and flexor carpi radialis brevis: a cadaveric study with clinical significance. International Journal of Anatomy and Research, 5(2.1), 36983703.

Capitanio, D., Moriggi, M., \& Gelfi, C. (2017). Mapping the human skeletal muscle proteome: progress and potential. Expert Review of Proteomics, 14(9), 825-839.

Colomar, J., Baiget, E., \& Corbi, F. (2020). Influence of strength, power and muscular stiffness on stroke velocity in junior tennis players. Frontiers in Physiology, 11, 196.

Elce, A., Cardillo, G., Ventriglia, M., Giordano, C., Amirante, F., Mazza, G., et al. (2017). Anthropometric characteristics of young Italian tennis players. Journal of Human Sport and Exercise, 12(3), 651-658.

Fields, K.B., \& Rigby, D. (2016). Muscular calf injuries in runners. Current Sports Medicine Reports, 15(5), 320-324.

Genevois, C., Creveaux, T., Hautier, C., \& Rogowski, I. (2015). Trunk and shoulder muscle coordination during one, two-handed medicine-ball side throws and tennis forehand drive. Journal of Athletic Enhancement, http://dx.doi.org/10.4172/2324-9080.1000201. 
Genevois, C., Reid, M., Rogowski, I., \& Crespo, M. (2015). Performance factors related to the different tennis backhand groundstrokes: a review. Journal of Sports Science and Medicine, 14(1), 194-202.

Hodde, F.L., Ioannou, C.I., \& Altenmuller, E. (2019). Mapping of finger fascicles within the flexor digitorum superficialis and profundus muscles. Muscle Nerve, 60(5), 579-582.

Ivančević, T., Jovanović, B., Đukić, M., Marković, S., \& Đukić, N. (2008). Biomechanical analysis of shots and ball motion in tennis and the analogy with handball throws. Facta Universitatis Series Physical Education and Sport, 6(1), 51-66.

Jarmey, D.C., \& Sharkey, J. (2015). The concise book of muscles, $3^{\text {rd }}$ Eds. California: North Atlantic Books.

Kumar, A., \& Kumar, A. (2017). Biomechanical comparison of two different variations of backhand drive in tennis. Indian Journal of Physical Education, Sports Medicine and Exercise Science. 17(1), 9-11.

Lai, A.K.M., Biewener, A.A., \& Wakeling, J.M. (2019). Muscle-specific indices to characterise the functional behaviour of human lower-limb muscles during locomotion. Journal of Biomechanics, 89, 134-138.

Larionov, A., Yotovski, P., \& Filgueira, L. (2018). A detailed review on the clinical anatomy of the pectoralis major muscle. SM Journal of Clinical Anatomy, 2(3), 1015.

Maharaj, J.N., Cresswell, A.G., \& Lichtwark, G.A. (2016). The mechanical function of the tibialis posterior muscle and its tendon during locomotion. Journal of Biomechanics, 49(14), 3238-3243.

Martin, C., Bideau, B., Delamarche, P., \& Kulpa, R. (2016). Influence of a prolonged tennis match play on serve biomechanics. PLOS ONE, 11(8), e0159979.

Myers, N.L., Kibler, W.B. (2018). Core stability in tennis players. In: G. Di Giacomo, T. Ellenbecker, \& W. Kibler, (Eds.), Tennis medicine. Springer.

Olewnik, L., Podgorski, M., Polguj, M. Ruzik, K., \& Topol, M. (2019). A cadaveric study of the morphology of the extensor hallucis longus - a proposal for a new classification. BMC Musculoskeletal Disorders, 20(1), 310.

Rodríguez, D.S., \& Del Valle, M. (2018). High-intensity specific intermittent training (SIT) in the preparation of the tennis player. Archivos de Medicina del Deporte, 35(6), 402-408.

Roeter, P., \& Kovacs, M. (2019). Tennis anatomy. Champaign, IL: Human Kinetics.

Saeki, J., Nakamura, M., Nakao, S., Fujita, K., Yanase, K., \& Ichihashi, N. (2018). Muscle stiffness of posterior lower leg in runners with a history of medial tibial stress syndrome. Scandinavian Journal of Medicine and Science in Sports, 28(1), 246-251.

Sanchis-Moysi, J., Dorado, C., Idoate, F., González-Henríquez, J.J., Serrano-Sanchez, J.A., \& Calbet, J.A.L. (2016). The asymmetry of pectoralis muscles is greater in male prepubertal than in professional tennis players. European Journal of Sport Science, 16(7), 780-786.

Save A.V., Fishman F.G. (2019). Tennis and golf wrist. In: A. Bauer \& D. Bae (Eds.), Upper extremity injuries in young athletes. contemporary pediatric and adolescent sports medicine. Springer, Cham.

Sawali, L. (2018). Arm muscle power and energy system measurement of forehand drive on tennis. International Research Journal of Engineering, IT and Scientific Research, 4(4), 30-39.

Tohanean, D.I. (2018). Motric activity - the main factor in preventing sedentary schooling in 12-14 year-old. Bulletin of the Transilvania University of Brasov, Series IX: Sciences of Human Kinetics, 11(60), 123-128.

Özek, S. (2020). Isolated long thoracic nerve injury case presentation: a sports injury. Acta Neurologica Belgica, 120(1), 199-200.

West, C.T., Ricketts, D., \& Brassett, C. (2017). An anatomical study of additional radial wrist extensors including a unique extensor carpi radialis accessories. Folia Morphologica, 76(4), 742-747.

Whiting, W.C. (2019) Dynamic human anatomy, $2^{\text {nd }}$ Eds. Champaign, IL: Human Kinetics.

Zdilla, M.J, Paulet, J.E., Lear, J.J., Addie, K.M., \& Lambert, H.W. (2018). A review of extensor hallucis longus variants featuring a novel extensor primi internodii hallucis muscle merging with extensor hallucis brevis. The Journal of Foot and Ankle Surgery, 57(6), 1218-1220.

Zhang, S., Fu, W., Pan, J., Wang, L., Xia, R., \& Liu, Y. (2016). Acute effects of Kinesio taping on muscle strength and fatigue in the forearm of tennis players. Journal of Science and Medicine in Sport, 19(6), 459-464. 


\section{AKTIVACIJA MIŠIĆA TOKOM FORHEND I BEKEND UDARACA U TENISU}

Tenis je jedan od najpopularnijih individualnih sportova širom sveta. Snaga i utreniranost mišića su neophodni igraču kako bi postigao dobar bekhend, forhend, volej ili ravni udarac. Tokom igranja tenisa uključene su brojne vrste mišića kao što su mišići donjeg dela tela, mišići trupa i mišići gornjeg dela tela. Cilj ovog preglednog rada je da predstavi mišiće aktivirane u osnovnim teniskim pokretima forhenda i bekhenda i da poboljša znanje o njihovoj ulozi kako bi se teniserima i trenerima pomoglo da poboljšaju svoje sportske učinke i smanje rizik od povreda. U cilju pregleda literature, podaci su prikupljeni iz baza podataka biblioteka i sa interneta koristeći ključne reči kao što su tenis, mišići, forhend, bekhend i u publikacijama između 2015. i 2019. godine. Ukupno je pronađeno i korišćeno trideset pet referenci. Literatura je pokazala da su forhend i backhand udarci koji uključuju mišiće ne samo gornjih ekstremiteta već $i$ niz složenih pokreta koji počinju u stopalima, a završavaju se zamahivanjem teniskog reketa. Uvid u delovanje mišića u tenisu treba koristiti kod tenisera kako bi se bolje razumele mišićne funkcije koje učestvuju u određenim teniskim pokretima i koje su važne za ostvarivanje boljeg sportskog učinka. Pored toga, ovo znanje se smatra izuzetno korisnim za trenere $i$ povoljnim za izgradnju trenažnog procesa.

Ključne reči: tenis, mišići, teniski udarac, forhend, bekend 